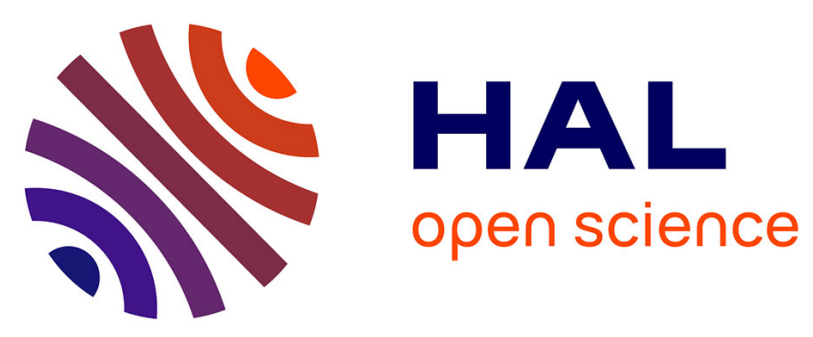

\title{
Identification and quantification of steroids in the serum of rainbow trout during spermiation and oocyte maturation
}

\author{
C. M. Campbell, Alexis Fostier, Bernard Jalabert, B. Truscott
}

\section{- To cite this version:}

C. M. Campbell, Alexis Fostier, Bernard Jalabert, B. Truscott. Identification and quantification of steroids in the serum of rainbow trout during spermiation and oocyte maturation. Journal of Endocrinology, 1980, 85 (3), pp.371-378. 10.1677/joe.0.0850371 . hal-01601581

\section{HAL Id: hal-01601581 \\ https://hal.science/hal-01601581}

Submitted on 2 Jun 2020

HAL is a multi-disciplinary open access archive for the deposit and dissemination of scientific research documents, whether they are published or not. The documents may come from teaching and research institutions in France or abroad, or from public or private research centers.
L'archive ouverte pluridisciplinaire HAL, est destinée au dépôt et à la diffusion de documents scientifiques de niveau recherche, publiés ou non, émanant des établissements d'enseignement et de recherche français ou étrangers, des laboratoires publics ou privés.

\section{다(1)(2)}

Distributed under a Creative Commons Attribution - ShareAlikel 4.0 International 
IDENTIFICATION AND QUANTIFICATION OF STEROIDS IN THE SERUM OF RAINBOW TROUT DURING SPERMIATION AND OOCYTE MATURATION

\author{
C. M. CAMPBELL* $\dagger, A$. FOSTIER* $\ddagger$, B. JALABERT* $\ddagger$ AND \\ B. TRUSCOTT $†$ \\ * Laboratoire de Physiologie des Poissons, Institut National de la Recherche \\ Agronomique, 78350 Jouy-en-Josas, France, and +Marine Sciences Research Laboratory, \\ Memorial University of Newfoundland, St John's, Newfoundland, Canada
}

(Received 12 June 1979)

SUMMAR Y

$17 \alpha$-Hydroxy-20 $\beta$-dihydroprogesterone and $17 \alpha$-hydroxyprogesterone were found in higher concentrations in serum from female Salmo gairdneri undergoing final oocyte maturation immediately before ovulation than in serum from spermiating male trout. Other steroids (11deoxycorticosterone, 11-deoxycortisol and progesterone) which have been implicated in oocyte maturation and/or ovulation in lower vertebrates were not identified at such high concentrations and the differences between the serum of both sexes were not so great. These results confirm that $17 \alpha$-hydroxy-20ß-dihydroprogesterone and $17 \alpha$-hydroxyprogesterone, the most potent inducers of trout oocyte maturation in vitro, are present in the blood when oocyte maturation occurs. The concentration of testosterone was found to be higher in serum from female than from male trout indicating that testosterone is unlikely to be the principal androgen in trout. High concentrations of 11 -oxotestosterone in male and barely detectable levels in female fish support the hypothesis that 11 -oxotestosterone is an important androgen in the regulation of testicular activity.

\title{
INTRODUCTION
}

Many steroids have been implicated in the control of oocyte maturation and ovulation but the steroids involved in spermatogenesis and spermiation remain to be identified in teleost fish. High concentrations in only one sex may indicate involvement in the reproductive processes specific to that sex at the time of sampling.

Jalabert (1976) and Jalabert, Goetz, Breton, Fostier \& Donaldson (1978) suggested that

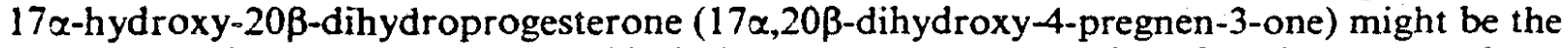
steroid mediator of gonadotrophin-induced oocyte maturation for Salmo gairdneri, Carassius auratus, Esox lucius, Cyprinus carpio and Oncorhynchus kisutch. This steroid was identified in plasma from sexually mature and spawned Oncorhynchus nerka and Salmo salar (Schmidt \& Idler, 1962). Samples of plasma from Pseudopleuronectes americanus which induced maturation of oocytes when assayed in vitro contained higher concentrations of $17 \alpha$-hydroxy-20ß-dihydroprogesterone than those samples without activity (Campbell, Walsh \& Idler, 1976). This steroid had not been identified previously in blood from $S$. gairdneri.

Other steroids investigated in the present study were progesterone and $17 \alpha$ hydroxyprogesterone (17 $\alpha$-hydroxy-4-pregnene-3,20-dione) which are potent maturation-

† Present address: Laboratoire de Physiologie des Poissons, A venue du Général Leclarc. B.P. 25A, 35042 Rennes, France. 


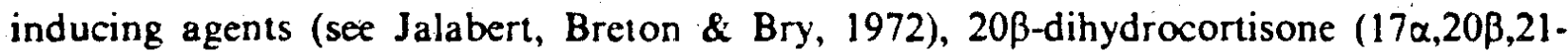
trihydroxy-4-pregnene-3,11-dione) found in plasma from spawned $O$. nerka (Idler, Schmidt \& Ronald, 1962), and 11-deoxycortisol (17 $\alpha, 21$-dihydroxy-4-pregnene-3,20-dione) and 11deoxycorticosterone, active in oocyte maturation of Heleropneusies fossilis (Sundararaj \& Goswami, 1977). Cortisol, a maturation-inducing steroid in catfish, was omitted from this study since the effects of stress might have obscured any differences.

Testosterone is androgenic in teleosts and has frequently been identified in body fluids and after incubation of tissues (see Ozon, 1972). Serum levels obtained by methods which may also be measuring other androgens are correlated with testicular activity (Schreck, Lackey \& Hopwood, 1974; Sanchez-Rodriguez, Escaffre, Marlot \& Reinaud, 1978). Wingfield \& Grimm (1977) found an annual cycle of concentrations of testosterone in the plasma of plaice of both sexes but Campbell et al. (1976) found that levels of testosterone are higher in female than in male flounder.

11-Oxytestosterone (17 $\beta$-hydroxy-4-androstene-3,11-dione) has been implicated in the regulation of spermatogenesis and spermiation of $O$. nerka and $S$. salar (see Idler, Horne \& Sangalang, 1971), P. americanus (Campbell et al. 1976) and Salvelinus fontinalis (Sangalang \& Freeman, 1974). Idler et al. (1971) found that levels of $11 \beta$-hydroxytestosterone (11 $\beta, 17 \beta$ dihydroxy-4-androsten-3-one) also increase with testicular development in $S$. salar but the physiological role of these androgens is unclear.

In the present study some key steroids have been identified and quantified by a doubleisotope derivative assay. The assay was performed on sera from male $S$. gairdneri which were producing sperm and from female trout which were undergoing final oocyte meiotic maturation but which had not yet begun to ovulate, to compare hormone profiles in both sexes at these defined states of reproductive activity.

\section{MATERIALS AND METHODS}

Blood was collected from more than 20 hatchery-reared male rainbow trout of $1-2 \mathrm{~kg}$ body weight in November/December 1976. The fish were checked for the presence of ripe spermatozoa by squeezing the abdomen. A few oocytes were stripped from female fish to assess the stage of oocyte maturation. Fifteen female trout were bled by syringe from a caudal vessel. The chosen fish had oocytes in the stages named 2, 3 and 4 by Jalabert (1978), in which germinal vesicles completely touch the oocyte membrane, or have undergone germinal vesicle breakdown and where maturation has progressed to follicular preparation for ovulation. Blood was allowed to clot and then centrifuged. Serum was pooled for each sex and stored at $-70^{\circ} \mathrm{C}$.

17 $\alpha$-Hydroxyprogesterone was isolated from $14 \mathrm{ml}$ serum from male and female trout. The other steroids were assayed in $13.7 \mathrm{ml}$ serum from female and $13.9 \mathrm{ml}$ from male animals.

The sources and preparation of reagents were the same as those described by Truscott, Idler, Sundararaj \& Goswami (1978). Radioinert and ${ }^{14} \mathrm{C}$-labelled 11 B-hydroxytestosterone and 11-oxotestosterone were prepared by the method described by Idler $e$ t al. (1971). Acetates of $11 \beta$-hydroxytestosterone, 11-oxotestosterone, 20 $\beta$-dihydrocortisone and $17 \alpha$ hydroxy-20ß-dihydroprogesterone for use in identification were prepared by the usual methods and purified by thin-layer chromatography (Idler et al. 1971).

Recovery tracers (purified ${ }^{14} \mathrm{C}$-labelled steroids) were added to the samples and extraction was performed as described by Truscott \& Idler (1972). Extracts were applied to silica gel thin-layer chromatography plates and developed in hexane:ethyl acetate $(80: 20, \mathrm{v} / \mathrm{v})$ and chloroform : methanol: water (188: $12: 1$, by vol.) together with steroids which were not to be assayed in order to isolate the desired steroids into five groups (Fig. 1) without the risk of any contamination. Progesterone and $17 \alpha$-hydroxyprogesterone were reduced with $20 \beta$-hydroxysteroid dehydrogenase (Simpson, Wright \& Hunt, 1964). The progesterone was isolated in fraction 1 (Fig. 1) but 17 $\alpha$-hydroxyprogesterone was isolated from pooled 
fraction 2 as fraction 6 (Fig. 1). The 17 $\alpha$-hydroxyprogesterone fractions were rechromatographed before reduction using testosterone as a marker to reduce any possible contamination by $17 \alpha$-hydroxy-20 $\beta$-dihydroprogesterone. After reduction, $17 \alpha$-hydroxy$20 \beta$-dihydroprogesterone and $20 \beta$-dihydroprogesterone were isolated using testosterone and 11-deoxycortisol as markers. The extracts and samples of tracers were acetylated using $100 \mathrm{mCi} / \mathrm{mmol}\left[{ }^{3} \mathrm{H}\right]$ acetic anhydride $(6 \mathrm{mCi} /$ tube $)$, the reaction conditions being similar to those of Truscott et al. (1978). Radioinert corticosterone was also acetylated to determine the exact specific activity of the ${ }^{3} \mathrm{H}$-labelled anhydride.

After re-extraction of the ${ }^{3} \mathrm{H}$-labelled acetylation mixtures, the sample fraction groups 1 , 3, 4, 5 and 6 (defined by Fig. 1) were chromatographed in System 1 (chloroform : methanol; $96: 4, \mathrm{v} / \mathrm{v})$ to separate individual steroid ${ }^{3} \mathrm{H}$-labelled acetates. The three ${ }^{3} \mathrm{H}$-labelled acetates to be isolated from group 2 were separated using chloroform : methanol : water $(188: 12: 1$, by vol.)

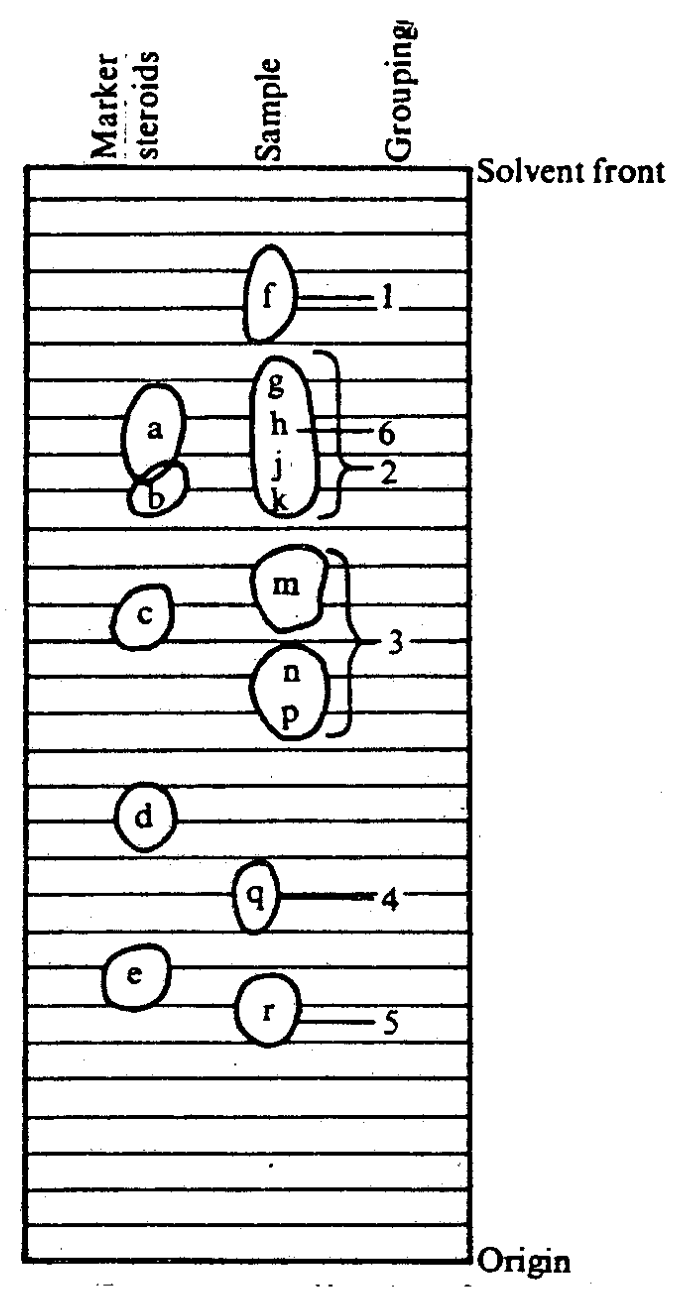

Fig. 1. Steroids were isolated by thin-layer chromatography in chloroform: methanol: water (188:12:1, by vol.) from pooled serum samples of both male and female trout. Steroids that were not being assayed were used as markers and were detected by absorbance of ultra-violet light and used to establish positions to elute steroid groups to be acetylated. $a=$ corticosterone acetate; $b=$ cortisone-21 acetate; $\mathrm{c}=$ cortisol-21-acetate; $\mathrm{d}=$ cortisone; $\mathrm{e}=$ cortisol; $\mathrm{f}=$ progesterone; $\mathrm{g}=$ deoxycorticosterone; $h=17 \alpha$-hydroxyprogesterone; $j=20 \beta$-dihydroprogesterone; $k=$ testosterone; $m=17 \alpha$-hydroxy-20 dihydroprogesterone; $\mathrm{n}=11$-deoxycortisol; $\mathrm{p}=11$-oxotestosterone; $q=11 \beta$-bydroxytestosterone; $r=20 \beta$-dihydrocortisone.

${ }^{3} \mathrm{H}$-Labelled acetates were further purified by thin-layer and paper chromatography (Table 1) and by crystallization from ethanol with water or acetone with pentane. In the case of samples where recovery was low, crystallization was performed but crystal samples were not taken each time. Counting was performed in a Packard 2425 using external standardization 
to estimate efficiency and ${ }^{14} \mathrm{C}$ spill into the ${ }^{3} \mathrm{H}$ channel (spill from ${ }^{3} \mathrm{H}$ into ${ }^{14} \mathrm{C}$ was negligible). Samples generally contained 100 to 300 disintegrations ${ }^{14} \mathrm{C} / \mathrm{min}$ and were counted to approximately 10000.

Table 1. Sequence of chromatography procedures used (and their composition) to purify the ${ }^{3} \mathrm{H}$-labelled acetates of steroids in the double isotope derivative assay of sera from rainbow trout

Chromatography system

\author{
Corticosterone \\ 11-Deoxycortisol \\ 11-Deoxycorticosterone \\ 20ß-Dihydroprogesterone \\ Testosterone \\ $17 \alpha$-Hydroxy-20ß-dihydroprogesterone \\ 11-Oxotestosterone \\ $11 \beta$-Hydroxytestosterone \\ 20ß-Dihydrocortisone
}

Thin-layer chromatography systems (by vol.)

1. Chloroform: methanol $(96: 4)$

2. Dichloromethane : $n$-butylacetate $(70: 30)$

3. Cyclohexane : isopropanol $(70: 30)$

4. Cyclohexane : ethyl acetate $(50: 50)$; irrigated twice

5. Benzene : ethyl acetate $(66: 33)$

\begin{tabular}{lllllll}
\hline 1 & 2 & 4 & B & C & 1 & - \\
1 & 3 & A & E & C & - & - \\
1 & 2 & A & E & C & $\bar{D}$ & - \\
1 & 3 & 5 & 2 & C & D & - \\
1 & 3 & 2 & C & E & C & D \\
1 & 3 & 2 & A & D & E & - \\
1 & 2 & 4 & C & A & C & - \\
1 & 4 & 2 & A & E & - \\
1 & 2 & 4 & E & A & - & -
\end{tabular}

Paper chromatography systems (by vol.)
A. Mesitylene : methanol : water
(50:33:16) (reversed phase)
B. Cyclohexane : benzene : methanol : water $(100: 40: 100: 20)$
C. Heptane : $80 \%$ methanol $(50: 50)$
D. Benzene : hexane : methanol : water $(33: 66: 80: 20)$
E. Cyclohexane : dioxane : methanol : water $(100: 100: 66: 33)$

\section{RESULTS}

The results of the experiment are given in Table 2. Constant isotope ratios indicating purity of the ${ }^{3} \mathrm{H}$-labelled acetates were attained in all cases except $11 \beta$-hydroxytestosterone in

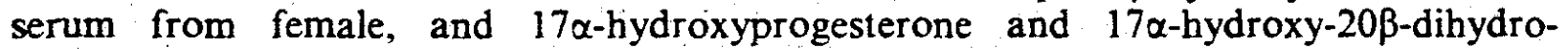
progesterone in that from male trout. In these cases the values calculated should represent the maximum possible value since purification tended to reduce the ratios.

\section{Discussion}

Within the limitations that these assays have measured only unconjugated steroids and that they take no account of the role of protein binding in the regulation of steroid action, it is possible to draw some conclusions based on a simplistic interpretation that high concentrations in serum may be indicative of some biological function. The samples for analysis were taken from both sexes at a physiological state which might be expected to involve changes in steroid profiles. The differences in concentrations of steroids between the sexes may be indicative of an association between high steroid concentration and oocyte maturation and ovulation in female trout, and spermiation in male trout.

In amphibia the most potent inducer of oocyte maturation is progesterone (Schuetz, 1967) but in trout the concentrations of progesterone were similar in male and female fish and the concentrations of $17 \alpha$-hydroxy-20 $\beta$-dihydroprogesterone and $17 \alpha$-hydroxyprogesterone were much higher in sera from female trout undergoing meiotic maturation. These results suggest that progesterone is not implicated in the maturation of oocytes of trout but that $17 \alpha$-hydroxy-20 $\beta$-dihydroprogesterone or " $17 \alpha$-hydroxyprogesterone may be the active 
Table 2. ${ }^{3} \mathrm{H}:{ }^{14} \mathrm{C}$ Ratios in aliquots of purified steroid ${ }^{3} \mathrm{H}$-labelled acetates after each paper chromatographic $\left(P_{1}, P_{2}\right)$ or crystallization $\left(C_{1}, C_{2}\right.$, etc. $)$ step. ${ }^{3} \mathrm{H}$-Labelled acetylated steroids were isolated from pooled sera from male $(M)$ and female $(F)$ rainbow trout. Constant isotope ratios $\left(^{*}\right)$ were used to calculate the concentration of the steroid in the original serum pool. For samples which were not purified to constant ratios the calculated values are maximal

\begin{tabular}{|c|c|c|c|c|c|c|c|c|}
\hline & & $\mathbf{P}_{1}$ & $\mathbf{P}_{\mathbf{2}}$ & $\mathrm{C}_{1}$ & $\mathrm{C}_{2}$ & $\mathrm{C}_{3}$ & $\mathrm{C}_{4}$ & $\begin{array}{c}\text { Concentration } \\
(\mathrm{ng} / \mathrm{ml})\end{array}$ \\
\hline Progesterone & $\begin{array}{l}\mathbf{M} \\
\mathbf{F}\end{array}$ & - & $\begin{array}{l}2.1 \\
2.3\end{array}$ & $\begin{array}{l}1.36 \\
1.71\end{array}$ & $\begin{array}{l}1.18^{\circ} \\
1.45^{*}\end{array}$ & $\begin{array}{l}0.99^{*} \\
1.33^{*}\end{array}$ & $\begin{array}{l}1.06^{*} \\
1.57^{*}\end{array}$ & $\begin{array}{l}1.7 \\
2.3\end{array}$ \\
\hline 17 $\alpha$-Hydroxyprogesterone & $\begin{array}{l}\mathbf{M} \\
\mathbf{F}\end{array}$ & $=$ & $\begin{array}{l}4.5 \\
94\end{array}$ & I & - & $\overline{99^{*}}$ & $\begin{array}{l}3.75 \\
101^{*}\end{array}$ & 82.8 \\
\hline 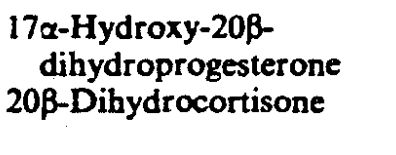 & $\begin{array}{l}\mathbf{M} \\
\mathbf{F} \\
\mathbf{M} \\
\mathbf{F}\end{array}$ & $\begin{array}{l}\bar{Z} \\
\frac{7 \cdot 2}{15 \cdot 6}\end{array}$ & $\begin{array}{l}7.9 \\
265 \\
6.0 \\
14.4\end{array}$ & $\begin{array}{l}\overline{346} \\
5 \cdot 9^{*} \\
14 \cdot 1^{*}\end{array}$ & $\begin{array}{l}- \\
338^{*} \\
5 \cdot 7^{*} \\
14 \cdot 2^{*}\end{array}$ & $\begin{array}{l}8 \cdot 2 \\
340^{*} \\
-\end{array}$ & $\begin{array}{l}7.2 \\
336^{*} \\
-\end{array}$ & $\begin{array}{l}\ll 9 \cdot 1 \\
480 \\
4 \cdot 5 \\
12 \cdot 3\end{array}$ \\
\hline 11-Deoxycortisol & $\begin{array}{l}\mathbf{M} \\
\mathbf{F}\end{array}$ & $=$ & $=$ & $\begin{array}{l}2.4^{*} \\
6.8\end{array}$ & $\begin{array}{l}2 \cdot 4^{\circ} \\
6 \cdot 9^{*}\end{array}$ & $\begin{array}{l}2.4^{*} \\
6.9^{*}\end{array}$ & $\begin{array}{l}2 \cdot 4^{*} \\
7.0^{*}\end{array}$ & $\begin{array}{l}4.8 \\
18 \cdot 1\end{array}$ \\
\hline 11-Deoxycorticosterone & $\begin{array}{l}\mathbf{M} \\
\mathbf{F}\end{array}$ & $=$ & $=$ & 3.4 & 3.0 & $\begin{array}{l}2 \cdot 9 \\
2 \cdot 1^{*}\end{array}$ & $\begin{array}{l}2 \cdot 8^{*} \\
2 \cdot 1^{*}\end{array}$ & $\begin{array}{l}3.1 \\
2.0\end{array}$ \\
\hline Testosterone & $\begin{array}{l}\mathrm{M} \\
\mathrm{F}\end{array}$ & $\begin{array}{l}31 \\
85\end{array}$ & $\begin{array}{l}28.8 \\
85.9\end{array}$ & $\begin{array}{l}29.5 \\
90.1\end{array}$ & $\begin{array}{l}29.8 \\
89.5\end{array}$ & $\begin{array}{l}29 \cdot 7 \\
89 \cdot 3^{*}\end{array}$ & $\begin{array}{l}29.7 \\
91.6\end{array}$ & $\begin{array}{l}59 \cdot 6 \\
187\end{array}$ \\
\hline 11-Oxotestosterone & $\begin{array}{l}\mathrm{M} \\
\mathrm{F}\end{array}$ & - & $\begin{array}{l}81 \\
1.8\end{array}$ & $\begin{array}{l}90.0^{*} \\
1.3^{*}\end{array}$ & $\begin{array}{l}90 \cdot 2^{*} \\
1.3^{*}\end{array}$ & $\begin{array}{l}91 \cdot 9^{*} \\
1 \cdot 3^{*}\end{array}$ & $\begin{array}{l}92.0^{*} \\
1.3^{*}\end{array}$ & $\begin{array}{l}98 \\
0.63\end{array}$ \\
\hline 11ß-Hydroxytestosterone & $\begin{array}{l}\mathbf{M} \\
\mathbf{F}\end{array}$ & $\begin{array}{l}2 \cdot 4 \\
1 \cdot 1\end{array}$ & - & $2 \cdot 5$ & $2 \cdot 3^{*}$ & $2 \cdot 3^{*}$ & $\frac{2 \cdot 2^{*}}{-}$ & $\begin{array}{l}1.8 \\
\ll 0.5\end{array}$ \\
\hline
\end{tabular}

agent as has been suggested by in-vivo and in-vitro studies on oocyte maturation (Fostier, Jalabert \& Terqui, 1973; Jalabert, Breton, Bryuska, Fostier \& Wienawski, 1977). Sundararaj \& Goswami (1977) suggested that 11-deoxycortisol or 11-deoxycorticosterone might be the maturation-inducing steroids of the catfish but Truscott et al. (1978) concluded that since secretion of these hormones into catfish plasma is stimulated neither by luteinizing hormone nor by adrenocorticotrophic hormone it is unlikely that they are involved. It has been found here, in agreement with Campbell et al. (1976) on flounder, that these steroids are not present in high concentrations during oocyte maturation and differences in the concentration of 11 deoxycorticosterone between male and female fish do not strongly support a hypothesis for a role for these steroids in oocyte maturation. Their function is far from clear since Colombo, Colombo-Belvedere \& Arcarese (1978) have indicated that 11-deoxycorticosteroids are more important metabolites in ovaries after ovulation than in the vitellogenic ovaries of Dicentrarchus labrax. Several studies have shown the oocytes of brook trout, killifish and zebra fish to be sensitive to both 11 -deoxycorticosteroids and progestagens (Van Ree, Lok \& Bosman, 1977; Goetz \& Bergman, 1978; Wallace \& Selman, 1978). The higher concentrations of 11-deoxycortisol in female trout might be related to the oocyte maturation occurring in these animals. In fact Jalabert (1975) showed that treatment with cortisol and cortisone increases the sensitivity of oocytes from $S$. gairdneri to gonadotrophin and steroid in vitro, but 11-deoxycortisol was not tested.

Idler $e$ t al. (1962) found significant levels of 20ß-dihydrocortisone in the blood of $O$. nerka after spawning and we have found higher concentrations in the serum of maturing female than of ripe male rainbow trout. Unfortunately, the biological activity of this steroid has not been tested so far.

Levels of testosterone are higher in female flounder than in male flounder at the spawning period (Campbell et al. 1976) and we have found that testosterone was present at high concentration in female trout undergoing oocyte maturation.

11-Oxygenated androgens have been isolated from cultures of guppy and eel ovaries (Lambert \& Pot, 1975; Colombo \& Colombo-Belvedere, 1977) but the results of the present 
study indicated that 11-oxygenated androgens were not to be found in significant quantities in sera from female fish whose oocytes were undergoing maturation. Using a radioimmunoassay, Simpson \& Wright (1977) found levels of $0.95-1.82 \mathrm{ng} 11$-oxotestosterone $/ \mathrm{ml}$ in ovulated female rainbow trout in comparison with $2-90 \mathrm{ng} / \mathrm{ml}$ in reproductively active male trout. Schmidt \& Idler (1962) detected 11-oxotestosterone in the blood of female Atlantic and Pacinic salmon but it is not a major steroid in the circulation of the female winter flounder and female rainbow trout undergoing normal oocyte maturation. Katz \& Eckstein (1974) identified 11-oxotestosterone in higher concentrations in individual Tilapia aurea in which oocyte maturation was apparently blocked and suggested an inhibitory function in the regulation of maturation and ovulation.

Male Pacific and Atlantic salmon have significant concentrations of 11-oxotestosterone and Campbell et al. (1976) postulated that 11-oxotestosterone might be a more active androgen in flounder than testosterone, because concentrations of this steroid are higher than those of testosterone in the plasma of the male animals. The present data are in accord with this suggestion. Idler, Bitners \& Schmidt (1961) found androgenic effects of 11 oxotestosterone on skin colour and thickness and some induction of spermiation in sockeye salmon and Arai (1967) showed 11-oxotestosterone to be a more potent androgen than testosterone for induction of male secondary sex characters in both sexes of Oryzias latipes.

$11 \beta$-Hydroxytestosterone was identified at low concentrations in both sexes of rainbow trout and has been identified as a metabolite of progesterone and androstenedione in cultures of trout ovaries (Arai \& Tamaoki, 1967) but no indication of a biological function can be given.

It is possible that the importance of testosterone for the male trout has been underestimated since it has been shown that more testosterone glucuronide is-produced than testosterone during in-vitro incubation of rainbow trout testis with precursors (Hews \& Kime, 1978).

This possibility and the unknown importance of protein binding must impose limitations on the interpretation of the present data. This analysis does, however, show which unconjugated steroids were present during oocyte maturation in female, and during spermiation in male rainbow trout. Further studies can now evaluate the physiological significance of the high concentrations found. $17 \alpha-\mathrm{Hydroxy}-20 \beta$-dihydroprogesterone, by being important in the induction of maturation of oocytes and by occurring at significant concentrations in the circulation at the appropriate time, must be proposed as the natural agent. Synthesis of the steroid during gonadotrophin-induced maturation must be demonstrated to complete the argument.

C.M.C. was supported by a Royal Society European Programme Fellowship. Our thanks to Dr D. R. Idler for providing the facilities of the Marine Sciences Research Laboratory, Memorial University of Newfoundland, St John's, Newfoundland and for supporting the study during a visit by $C$. M. C. The study was funded from a grant from 'Le Ministere de l'Environment et de la Culture'. MSRL Contribution number 367.

\section{REFERENCES}

Arai, R. (1967). Androgenic effects of 11-ketotestosterone on some sexual characteristics in the teleost, Oryzias Latipes. Annolationes Zoologicae Japonenses 40, 1-5.

Arai, R. \& Tamaoki, B. I. (1967). Steroid biosynthesis in vitro by testes of rainbow trout, Salmo gairdneri. General and Comparative Endocrinology 8, 305-313.

Campbell, C. M., Walsh, J. M. \& Idler, D. R. (1976). Steroids in the plasma of the winter flounder (Pseudopleuronectes americanus Walbaum). A seasonal study and investigation of steroid involvement in oocyte maturation. General and Comparative Endocrinology 29, 14-20.

Colombo, L. \& Colombo-Belvedere, P. (1977). Gonadal steroidogenesis in teleost fishes. Investigación Pesquera 41, 147-164. 
Colombo, L., Colombo-Belvedere, P. \& Arcarese, G. (1978). Emergence of ovarian 11-deoxycorticosteroid biosynthesis at ovulation time in the sea bass, Dicentrarchus labrax L. Annales de Biologie Animale. Biochimie et Biophysique 18, 937-941.

Fostier, A., Jalabert, B. \& Terqui, M. (1973). Action prédominante d'un derivé hydroxylé de la progestérone sur la maturation in-vitro des ovocytes de la truite arc-en-ciel Salmo gairdneri. Comptes Rendus Hebdomadaires des Séances de l'Académie des Sciences 277D, 421-424.

Goetz, F. W. \& Bergman, H. L. (1978). The effects of steroids on final maturation and ovulation of oocytes from brook trout (Salvelinus fontinalis) and yellow perch (Perca florescens). Biology of Reproduction 18, $293-298$.

Hews, E. A. \& Kime, D. E. (1978). Formation of testosterone glucuronide by testes of the rainbow trout, Salmo gairdneri. General and Comparative Endocrinology 34, 116-119.

Idler, D. R., Bitners, I. I. \& Schmidt, P. J. (1961). 11-Ketotestosterone: an androgen for sockeye salmon. Canadian Journal of Biochemistry and Physiology 39, 1737-1742.

Idler, D. R., Horne, D. A. \& Sangalang, G. B. (1971). Identification and quantification of the major androgens in testicular and peripheral plasma of Atlantic salmon (Salmo salar) during sexual maturation. General and Comparative Endocrinology 16, 237-267.

Idler, D. R., Schmidt, P. J. \& Ronald, A. P. (1962). Isolation of 20ß-dihydrocortisone from sockeye salmon . (Oncorhynchus nerka) plasma. Canadian Journal of Biochemistry and Physiology 40, 549-553.

Jalabert, B. (1975). Modulation par differents steroides non-maturants de l'efficacité de la $17 \alpha$-hydroxy-20ßdihydroprogesterone ou d'un extrait gonadotropique sur la maturation intrafolliculaire in vitro des ovocytes de la truite arc-en-ciel Salmo gairdneri. Comptes Renüus Hebdomadaires des Séances de l'Académie des Sciences 281D, $811-814$.

Jalabert, B. (1976). In-vitro oocyte maturation and ovulation in rainbow trout (Salmo gairdneri), northern pike (Esox lucius) and goldfish (Carassius auratus). Journal of the Fisheries Research Board of Canada 33, 974-988.

Jalabert, B. (1978). Production of fertilizable oocytes from follicles of rainbow trout (Salmo gairdneri) following in vitro maturation and ovulation. Annales de Biologie Animale. Biochimie et Biophysique 18, 977-984.

Jalabert, B., Breton, B. \& Bry, C. (1972). Maturation et ovulation in-vitro des ovocytes de la truite arc-en-ciel, Salmo gairdneri. Comptes Rendus Hebdomadaires des Séc.ces de I Académie des Sciences 275D, 1139-1142.

Jalabert, B., Breton, R., Bryuska, E., Fostier, A. \& Wienawski, J. (1977). A new tool for induced spawning: the use

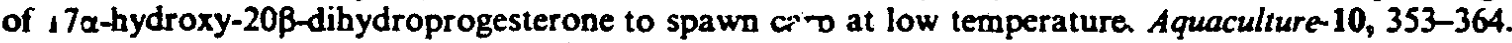

Jalabert, B., Goetz, F. W., Breton, B., Fostier, A. \& Dunaluson, E. M. (1978). Precocious induction of oocyte maturation and ovulation in coho salmon, Oncorhynchus kisutch. Journal of the Fisheries Research Board of Canada 35, 1423-1429.

Katz, Y. \& Eckstein, B. (1974). Changes in the steroid concentration in blood of female Tilapia aurea (Teleostei, cichlidae) during initiation of spawning. Endocrinology 95, 963-967.

Lambert, J. G. D. \& Pot, M. G. E. (1975). Steroidogenesis in ovarian tissue of a viviparous teleost, the guppy Poecilia reticulata. Comparative Biochemistry and Physiology 50B, 585-589.

Ozon, R. (1972). Androgens in fishes, amphibians, reptiles and birds. In Steroids in non-mammalian vertebrates, pp. 328-389. Ed. D. R. Idler. New York:Academic Press.

Sanchez-Rodriguez, M., Escaffre, A. M., Marlot, S. \& Reinaud, P. (1978). The spermiation period in the rainbow trout (Salmo gairdneri). Plasma gonadotropin and androgen levels, sperm production and biochemical changes in the seminal fluid. Annales de Biologie Animale Biochimie et Biophysique 18, 943-948.

Sangalang, G. B. \& Freeman, H. C. (1974). Effects of sublethal ci \&nium on maturation and testosterone and 11 ketotestosterone production in vivo in brook trout. Biology of Reproduction 11, $429-435$.

Schmidt, P. J. \& Idler, D. R. (1962). Steroid hormones in the plasma of salmon at various stages of maturation. General and Comparative Endocrinology 2, 204-214.

Schreck, C. B., Lackey, R. T. \& Hopwood, M. L. (1974). Seasonal androgen and estrogen patterns in the goldfish Carassius auraius. Transactions of the American Fisheries Saciety 103, 375-378.

Schuetz, A. W. (1967). Effect of steroids on the germinal vesicles of the frog (Rana pipiens) oocytes. Proceedings of the Society for Experimental Biology and Medicine 124, 1307-1310.

Simpson, T. H. \& Wright, R. S. (1977). A radioimmunoassay for 11-oxotestosterone: its application in the measurement of levels in blood serum of rainbow trout ( $S$. gairdneri). Steroids 29, 383-398.

Simpson, T. H., Wright, R. S. \& Hunt, S. V. (1964). Steroid biosynthesis in the testis of dogfish (Squalus acanthias). Journal of Endocrinology 31, 20-38.

Sundararaj, B. I. \& Goswami, S. V. (1977). Hormonal regulation of in vivo and in vitro oocyte maturation in the catfish, Heteropneustes fossilis (Bloch). General and Comparative Endocrinology 32, 17-28.

Truscott, B. \& Idler, D. R. (1972). Corticosteroids in plasma of elasmobranchs. Comparative Biochemistry and Physiology 42A, 41-50.

Truscott, B., Idler, D. R., Sundararaj, B. I., \& Goswami, S. V. (1978). Effects of gonadotropins and adrenocorticotropin on plasmatic steroids of the catfish, Heteropneustes fossilis (Bloch). General and Comparative Endocrinology 34, 149-157.

Van Ree, G., Lok, D. \& Bosman, G. J. C. G. M. (1977). In vitro induction of nuclear breakdown in oocytes of the zebra fish. Brachydanio rerio (Hamm. Buch). Effects of the composition of the medium and of protein and steroid hormones. Proceedings. Koniklijke Nederlandse Akademie van Wetenschappen 80C, 353-371. 
Wallace, R. A. \& Selman, K. (1978). Oogenesis in Fundulus heteroclitus. I. Preliminary observations on oocyre maturation in virro. Developmental Biology 62, 354-369.

Wingfield. J. C. \& Grimm, A. S. (1977). Seasonal changes in plasma cortisol, testosterone and oestradiol-17ß in the plaice Pleuronectes platessa. General and Comparative Endocrinology 31, 1-11. 